\title{
Poimanje distanazije i transhumanizma iz perspektive sestrinske profesije
}

\author{
Terezija Gložinić*, Odilon-Gbènoukpo Singbo**, Anto Čartolovni***
}

\begin{abstract}
Sažetak
Rad prezentira rezultate istraživanja o stavovima studenata preddiplomskoga studija sestrinstva na Hrvatskom katoličkom sveučilištu o praksi produženja života, o terapijskoj upornosti, tj. o distanaziji i o utjecaju transhumanističkih ideja na čovjekov život i na njihovu (buduću) sestrinsku profesiju. Istraživanje obuhvaća i stavove o smrti te o samom produljivanju ljudskoga života. Na temelju rezultata autori zaključuju da postoje razlike u stavovima i u poznavanju pojmova, koje su uglavnom povezane s radnim iskustvom $i$ vrstom studija.
\end{abstract}

Ključne riječi: distanazija; transhumanizam; eutanazija; ranjivost; sestrinska struka; produžavanje života; tehnologija

\section{Uvod}

U posljednjih nekoliko godina znanstveno-tehnička paradigma znatno se je promijenila i donijela čovječanstvu iznenađujući napredak kako u borbi protiv raznih bolesti, tako i u želji za dugim, bezbrižnim i ispunjenim životom. Distanazija vuče korijene iz grčkoga jezika i kovanica je od dviju riječi dys i thanatos, što u prijevodu znači "otežana smrt", "smrt sa zaprjekom". Manifestirajući se najčešće u obliku terapijske upornosti zadržavanja čovjeka na životu i ne dopuštanju da umire, unatoč medicinskoj nesvrsishodnosti, tj. očiglednomu nedostatku objektivnoga medicinskoga razloga za to, zbog želje (pacijenta ili rodbine) za produljenjem života, ili pak nesigurnosti medicinskoga zdravstvenoga osoblja kako postupati u pojedinim situacijama. Drugim riječima, praksa s kojom se općenito biomedicinska profesija, a osobito sestrinska, suočava u svakodnevnom radu s pacijentima popraćena je raznim moralno-antropološko-duhovnim dilemama, koje mogu otežavati njezin rad i brigu za čovjeka u terminalnoj fazi života. Sva-

* Terezija Gložinić, univ. bacc. med. techn., Hrvatsko katoličko sveučilište, Odjel za sestrinstvo, Adresa: Ilica 242, 10000 Zagreb, Hrvatska. ORCID iD: https://orcid.org/0000-0002-0219-756X. E-adresa:tglozinic@unicath.hr

** Dr. sc. Odilon-Gbènoukpo Singbo, Hrvatsko katoličko sveučilište, Katedra za teologiju. Adresa: Ilica 242, 10000 Zagreb, Hrvatska. ORCID iD: https://orcid.org/0000-0002-2154-8935. E-adresa: odilonsing@gmail.com

*** Doc. dr. sc. Anto Čartolovni, Hrvatsko katoličko sveučilište, Laboratorij za etiku digitalnih tehnologija u zdravstvu (Digit-HeaL). Adresa: Ilica 242, 10000 Zagreb, Hrvatska. ORCID iD: https://orcid.org/0000-0001-9420-0887 E-adresa: anto.cartolovni@unicath.hr 
kodnevni rad na odjelima palijativne skrbi ili pak onkološkim odjelima donosi različite dvojbe po pitanju uporabe određenih sredstava koja bi u drugim situacijama mogla spadati u redovita sredstva, a u takvim slučajevima njihova uporaba postaje besmislena gubeći svoju svrsishodnost. Među takvim je poznatim dvojbama i pitanje reanimacije. U pojedinim terminalnim slučajevima takvo postupanje ne pruža određenu dobrobit pacijentu, nego zapravo produžava agoniju i patnju poradi "ideologiziranoga" produžetka života. Na tragu takvoga "ideologiziranoga" stava prema životu 20. stoljeće donijelo je novi znanstveno-tehnički pokret pod nazivom transhumanizam. Transhumanizam je pokret koji smatra poželjnim, pa čak i obvezujućim korištenje dostignuća suvremenih tehnologija s ciljem poboljšanja čovjeka u morfološkom, kognitivnom i duhovnom smislu. No, za razliku od današnje medicine, koja je usmjerena na uporabu tehnologija $\mathrm{u}$ restorativne svrhe povratka izgubljenih funkcija, transhumanizam promovira korištenje tehnologije za nadilaženje postojećih ljudskih funkcija, poprimajući naposljetku čak i eugenički oblik. Transhumanizam, za razliku od prijašnjih ideologija, zadire duboko u pore medicine i zdravstvene skrbi, mijenjajući njezinu cjelokupnu teleologiju iz medicine koja odgovara na pacijentove medicinske potrebe u medicinu koja ispunjava želje. Takav paradigmatski skok već je zahvatio određene segmente medicine, što se vidi u terminološkim promjenama unutar zdravstvene skrbi, gdje osoba u potrebi više nije pacijent, nego zapravo klijent ili pak korisnik usluga. Štoviše, transhumanisti ulažu velike nade i sredstva u biomedicinska istraživanja osobito u područjima antiaging medicine, različitih terapija telomerazom ili pak kriogenoga zamrzavanja. Takav (in)direktan upliv transhumanizma u medicinu i postojeća uvriježena praksa distanazije neizbježno utječu na sestrinsku praksu te postaju bioetički izazovi koji zaslužuju znanstvenu pozornost kako u jednostavnom shvaćanju njihova značenja, tako i u raskrinkavanju njihove unutarnje dinamike. Dakako da treba imati na umu i pojam eutanazije, koji doslovno preveden znači "lijepa smrt” (grč. eu, lijepo, dobro; thanatos, smrt), a neki ju smatraju činom dostojanstvene smrti. Često se u razumijevanju distanazija krivo poistovjećuje s eutanazijom, osobito u kontekstu dostojanstvene smrti. Stoga je jedan od ciljeva ovoga istraživanja ispitati razumijevanje razlike između ta dva termina kod studenata. Nema dvojbe da je sestrinska profesija jedna od onih koje se brinu za kvalitetu života i za brigu o životu u osjetljivim i bolnim trenutcima. Ta profesija po svojoj naravi ide za poštivanjem nepovredivoga dostojanstva čovjeka bez obzira na njegovo zdravstveno stanje. Stoga je nužno potrebno da budući i glavni akteri takve profesije kroz obrazovanje budu informirani i formirani protiv mogućih prijetnji i prepreka u vršenju njihova plemenitoga zvanja. Potaknuti željom za informiranjem i razjašnjavanjem pojmova te za shvaćanjem njihova načina djelovanja, provedeno je istraživanje Distanazija i utjecaj transhumanizma na sestrinsku skrb među studentima preddiplomskoga studija sestrinstva (redovnim i izvanrednim) Hrvatskoga katoličkoga sveučilišta.

Opći je cilj istraživanja ispitati stavove spomenutih studenata o produženju života, terapijskoj upornosti (distanaziji) i utjecaju transhumanističkih ideja na čovjekov život i sestrinsku praksu. Uz opći cilj, postoji nekoliko specifičnih ciljeva. 
Prvi je utvrditi postoji li razlika u stavovima studenata redovnoga i izvanrednoga studija o transhumanističkim idejama i njihovu utjecaju na sestrinsku praksu. Drugi je cilj ispitati stavove o smrti kao neizbježnoj sastavnici ljudskoga života te samom produljivanju života. Osim toga, želi se kod studenata ispitati poznavanje pojma distanazije, kao i njezine pojave u svakodnevnoj sestrinskoj praksi. Treći je cilj ispitati postoji li razlika između studenata koji imaju radnoga iskustva u struci i onih koji ga nemaju u poznavanju pojma distanazije i njezinih implikacija.

Uz anonimni anketni upitnik bio je priložen informirani pristanak u kojem su predstavljeni tema i cilj istraživanja, kao i mogući rizici, neugodnosti i koristi od istraživanja. Sudjelovanje u istraživanju bilo je dragovoljno te su ispitanici u bilo kojem trenutku mogli odustati od ispunjavanja upitnika, štoviše u slučaju nedoumica i pitanja upućeni su na kontakt podatke samih istraživača. Svi podatci koji su prikupljeni obrađeni su grupno, čime je, pored anonimnosti, osigurana povjerljivost i zaštita podataka.

S obzirom na naznačene ciljeve, u radu postavljamo dvije radne hipoteze: Hipoteza 1: Prihvaćanje transhumanističkih ideja povezano je s postojanjem radnoga iskustva u struci. Hipoteza 2: Poznavanje tematike i razlikovanje distanazije i posljedica napretka ovisi o vrsti studija i postojanju radnoga iskustva u struci.

\section{Metodološke napomene}

$\mathrm{U}$ ovom istraživanju sudjelovalo je 164 ispitanika $(\mathrm{N}=164)$. Ispitanici su studentice i studenti preddiplomskoga studija sestrinstva na Hrvatskom katoličkom sveučilištu. Obuhvaćeni su studenti redovnoga i izvanrednoga studija prve, druge i treće godine preddiplomskoga studija. Za studente izvanrednoga studija podrazumijeva se da su starije životne dobi, za razliku od redovnih studenata, te da imaju više godina radnoga iskustva u struci. Uzorak je neprobabilistički prigodni.

U Tablici 1 prikazana su obilježja ispitanika koja uključuju spol, vrstu studija te postojanje radnoga iskustva u struci. S obzirom na to da je razlika u spolu statistički značajna, ${ }^{1}$ ne može se učiniti relevantna usporedba te ćemo se u rezultatima referirati na razliku između ispitanika s obzirom na radno iskustvo i vrstu studija.

Tablica 1. Obilježja uzorka

Table 1. Sample description

\begin{tabular}{|l|l|c|c|}
\hline \multicolumn{2}{|c|}{ Obilježje ispitanika } & $\begin{array}{c}\text { Broj } \\
\text { ispitanika }\end{array}$ & Postotak \\
\hline \multirow{2}{*}{ Spol } & Muško & 15 & $9,1 \%$ \\
\cline { 2 - 4 } & Žensko & 149 & $90,9 \%$ \\
\hline \multirow{2}{*}{ Vrsta studija } & Redovni studij & 85 & $52,5 \%$ \\
\cline { 2 - 4 } & Izvanredni studij & 77 & $47,5 \%$ \\
\hline \multirow{2}{*}{$\begin{array}{l}\text { Radno } \\
\text { iskustvo }\end{array}$} & Posjeduje radno iskustvo & 93 & $57,1 \%$ \\
\cline { 2 - 4 } & Ne posjeduje radno iskustvo & 70 & $42,9 \%$ \\
\hline
\end{tabular}

1 Veliki broj ispitanika pripada ženskomu spolu (90,9\%), a manji muškomu $(9,1 \%)$. 
Instrument je istraživanja anketni upitnik izrađen radi ovoga istraživanja koji sadrži četrdeset pitanja podijeljenih u nekoliko tematskih područja. Prvi dio uključuje socio-demografska pitanja koja ispituju spol, vrstu studija sestrinstva (redovni studij ili izvanredni studij) te postojanje radnoga iskustva ispitanika u sestrinskoj profesiji. Ostatak ankete čine pitanja koja ispituju stavove ispitanika, a podijeljena su u nekoliko tematskih cjelina: pitanje napretka i poboljšanja života, terapijska upornost ili distanazija, čovjekova vulnerabilnost u svjetlu transhumanističkih ideja te napredna tehnologija i sestrinska skrb.

Istraživanje je provedeno tijekom ožujka 2019. godine na Hrvatskom katoličkom sveučilištu dijeljenjem anketnih upitnika studentima sestrinstva svake pojedine godine preddiplomskoga studija. Podatci su obrađeni u statističkom programu IBM SPSS Statistics 23. Razina statističke značajnosti određena je na razini vjerojatnosti od $95 \%(\mathrm{p}<0,05)$.

\section{Prikaz i osnovna analiza rezultata}

\subsection{Ljudsko poboljšanje i nutarnja ispunjenost}

Deskriptivnom analizom podataka, odnosno određivanjem frekvencija pojedinih odgovora, dobiveni su sljedeći rezultati. Ideja napretka zauzima centralno mjesto u transhumanističkim raspravama, te njegovo nadasve različito poimanje utječe na pitanja unaprjeđenja i poboljšanja čovjeka. Na upit o toj temi naši ispitanici odgovaraju kako je prikazano u Grafikonu 1. Što se tiče fizičkoga poboljšanja, ne predstavljaju sva poboljšanja prijetnju našoj ljudskosti. Naši ispitanici smatraju da bioničko uho koje može čuti i one frekvencije koje nisu svojstvene biološkomu uhu ne predstavlja prijetnju samoj ljudskoj naravi. Štoviše $47,2 \%$ ispitanika se u potpunosti ne slaže s tvrdnjom da takvo uho predstavlja prijetnju čovjekovoj naravi.

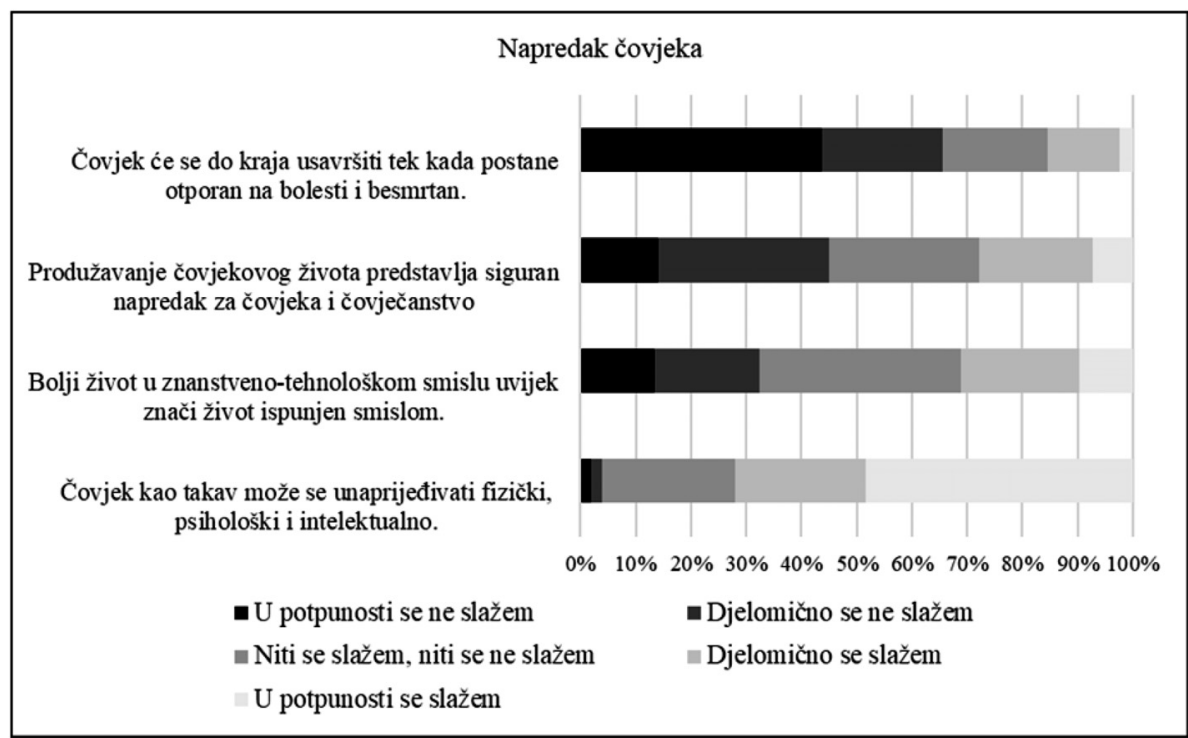

Grafikon 1. Kvaliteta života kroz znanstveno-tehničko poboljšanje čovjeka

Chart 1: Quality of life through scientific-technical human enhancement 
Transhumanizam kroz poboljšanje čovjeku obećava potpuno ispunjenje njega kao čovjeka. Na osnovu rezultata istraživanja može se uočiti mala pozitivna korelacija $\left(\mathrm{r}_{\mathrm{s}}=0,223 ; \mathrm{p}<0,05\right)$ koja upućuje na povezanost između postojanja radnoga iskustva i prihvaćanja ideje transhumanizma o ispunjenju čovjeka kroz produženje života. Naime, na tvrdnju koja potvrđuje ispunjenje čovjeka u njegovoj ljudskosti i ostvarenja temeljnih čežnji kroz produženje čovjekova života djelomično slaganje izrazilo je 5,8\% ispitanika s radnim iskustvom te $23,7 \%$ ispitanika bez radnoga iskustva, što je prikazano u Grafikonu 2. Dakle, studenti koji nemaju radnoga iskustva u većoj mjeri prihvaćaju tu ideju.



Grafikon 2. Stavovi o suodnosu produženja života i unutarnjega čovjekova zadovoljstva

Chart 2: Attitudes about life extension and human inner fulfillment

Glavni je cilj transhumanističke ideje bijeg od onoga karakterističnoga za njega, a to je ranjivost i smrtnost. Upravo je ta ranjivost ono esencijalno privrženo njegovoj naravi i ljudskosti. Naši ispitanici isto tako smatraju kako je čovjekova ranjivost dio njegove ljudskosti te da ni na koji način ne umanjuje njegovo dostojanstvo. Također, čovjekovu smrtnost, starenje i podložnost bolestima najveći dio ispitanika, tj. 37,8\% ne smatra izvorima problema i poniženja samoga čovjeka. $\mathrm{S}$ druge strane, $30,5 \%$ ispitanika smatra kako ne bismo trebali samo prihvaćati svoju ljudsku ranjivost, nego činiti sve kako bismo ju pobijedili. Na tvrdnju da je čovjekova ranjivost izraz njegove nesavršenosti, $26,2 \%$ ispitanika izrazilo je potpuno neslaganje, a u samo malo manjem postotku $23,2 \%$ izrazili su potpuno slaganje s tom tvrdnjom. Isto tako $43,6 \%$ ispitanika u potpunosti se slaže s izjavom da je ranjivost čovjeka ključno pitanje u sestrinskoj profesiji jer je cilj sestrinske prakse upravo pomoći pacijentu i zaštititi ga.

Neosporivo je da napredak medicine donosi mnoge promjene na području skrbi za bolesnika, što pokazuje Grafikon 3, a to je i potvrdilo 25,2\% ispitanika. Sve veći sadašnji, ali i budući znanstveno-tehnološki napredak zasigurno će na- 
metnuti pitanja poput onoga može li robot zamijeniti zdravstvenoga djelatnika. Pojava robotike u okviru sestrinske struke može doprinijeti njezinu poboljšanju, poput robota koji će pripomoći u podizanju pacijenata, no postoje idejna rješenja za robote koji bi provodili kompletnu njegu, tj. određena supstitucija za nedostatak sestrinske radne snage i odgovor na starenje društva i sve veći broj potrebitih za njegom. Štoviše, takva kompletna supstitucija sestrinskoga susreta s pacijentom predstavlja etički i moralni problem, jer sestrinska skrb predstavlja puno više od mehaničkoga obavljanja njege, poput osobnoga i empatijskoga susreta dvije osobe na putu iscjeljenja. Na tvrdnju "Pojava robota u medicini predstavlja prijetnju za medicinske djelatnike" ispitanici su se u najvećem postotku izjasnili neutralno, njih $27,2 \%$, a $21 \%$ ispitanika izrazilo je djelomično slaganje s izjavom. Također, $67,1 \%$ ispitanika, što čini znatnu većinu, smatra da primjena visokih tehnologija u medicini ne može zamijeniti ljudsku brigu, ohrabrenje, lijepu riječ i dodir.

Statistički značajna razlika između redovnih i izvanrednih studenata uviđa se kod stavova vezanih za ishode napretka tehnologije i njegovih posljedica na čovjeka prikazana u Grafikonu 3.

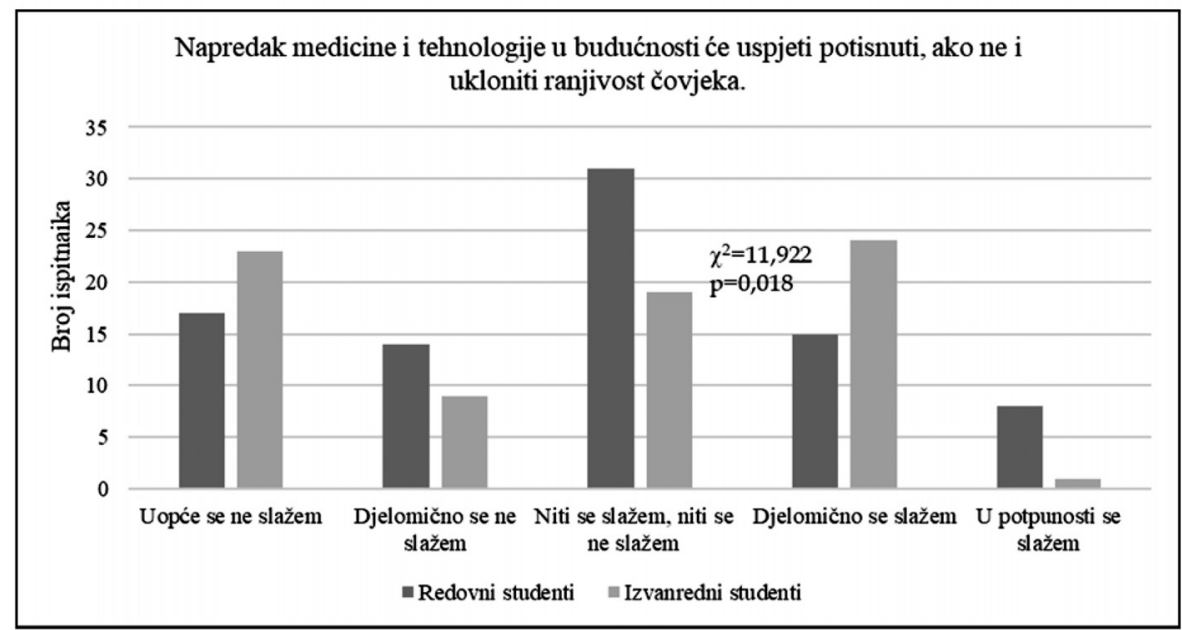

Grafikon 3. Ljudska vulnerabilnost u svjetlu biomedicinsko-tehnološkog napretka Chart 3: Human vulnerability in the light of biomedical-technological progress

\subsection{Distanazija: moralni i profesionalni izazov produljenja ljudskoga života}

Produžavanje života u transhumanističkom viđenju smatra se poželjnim i potrebnim, a u stvarnom životu i praksi produžavanje života poprima i onu drugu formu nepotrebnoga, beskorisnoga i neželjenoga u obliku distanazije. Kako bi se moglo raspravljati o distanaziji — čija je definicija naznačena u uvodnom dijelu — potrebno je znati značenje i definiciju samoga pojma, jer se često i krivo distanazija poima kao oblik dostojanstvene smrti, pa tako na tvrdnju da distanazija označava dostojanstvenu smrt 38,3\% ispitanika daje neutralan odgovor. No, valja zamijetiti kako je ipak veći broj redovnih studenata, njih 30,1\%, za razliku od $19,48 \%$ izvanrednih, izjavilo potpuno neslaganje s tom tvrdnjom. 
Osim definicije distanazije, jedno od područja koja su se željela ispitati utjecaj je distanazije na život kako pacijenta, tako i njegove obitelji. Najveći broj ispitanika smatra kako se produžavanjem života bolesnika ne smanjuje patnja pacijenta i obitelji. Napredak medicine i tehnologije donio je mnoge načine i sredstva kojima se život pacijenata produžuje. Vezano za načine i sredstva kojima se distanazija provodi, odnosno vezano za tvrdnju koja ističe da je opravdano koristiti sva moguća i dostupna sredstva kako bi se produžio život bolesnika, najviše je ispitanika, njih 28,4\% izrazilo ni slaganje ni ne slaganje, a prema frekvencijama na drugom mjestu potpuno je slaganje izjavilo $26,5 \%$ ispitanika. Isto tako, da se beziznimnim dobrom može smatrati sve, tj. svaki način i sredstvo koje može pobijediti bolest i produžiti život djelomično se slaže više izvanrednih studenata, njih $33,7 \%$, a najveći se je broj redovnih studenata izjasnio neutralno po tom pitanju.

Distanazija se naziva još i terapijska beskorisnost ili upornost (Vuletić et al., 2014) upravo zato što određeni postupak koji se pruža pacijentu nema pozitivne učinke na njegovo zdravlje i stanje, nego samo produžuje život i pojačava patnju. S obzirom na to, najveći broj od 34,6\% ispitanika izrazilo je potpuno slaganje s tvrdnjom koja izriče da dok god postoji nada za život, ne može se ni jedan medicinski postupak smatrati beskorisnim i financijskim opterećenjem za društvo, što je prikazano u Grafikonu 4. Kako liječnik ima veliku ulogu u procesu distanazije jer propisuje terapiju ili postupak, ili ga s druge strane dokida, u anketi su studenti pitani o njihovu stavu prema liječnikovim ovlastima u situacijama kada se provodi distanazija. Da liječnik ima pravo poduzeti sve što je u moći medicine kako bi produžio pacijentov život, smatra najveći dio, tj. 30,7\% izvanrednih studenata, a $37,7 \%$ redovnih studenata u najvećem dijelu zauzelo je neutralan stav prema tom pitanju.

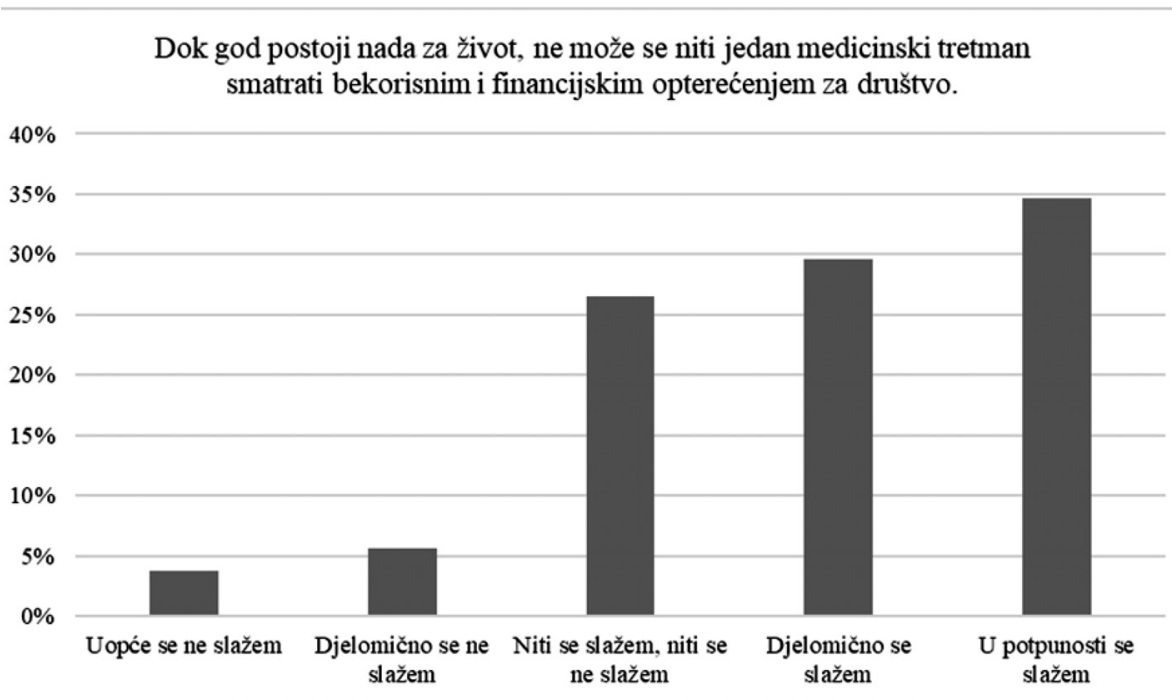

Grafikon 4. Stavovi o beskorisnosti medicinskih postupaka

Chart 4: Attitudes about the futility of medical procedures 
U kontekstu govora o produživanju života, nemoguće je ne dotaknuti se pojma kvalitete života. Vezano uz to, većina ispitanika, njih 59,5\% smatra (u potpunosti se slaže) kako kvaliteta života ima veću važnost od produženja života, a s druge strane 20,1\% ispitanika djelomično se slaže s izjavom da pacijente u trajnom vegetativnom stanju treba održavati na životu te da nije moralno obustaviti mehaničku ventilaciju ili umjetno hranjenje.

\subsection{Zastupljenost eutanazije i distanazije u medicinskoj praksi}

Kako bi se pokazalo razlikovanje distanazije i eutanazije kod studenata, nekoliko je pitanja bilo povezano s tom tematikom. Na tom su području nađene statistički značajne razlike. Naime, na tvrdnju "Eutanazija se provodi češće nego distanazija" 53,9\% izvanrednih studenata izjavilo je neodređen stav, a najveći je broj redovnih $(32,5 \%)$ zaokružilo broj 2, odnosno izrazilo djelomično neslaganje $(\mathrm{p}=0,03)$, što je prikazano u Grafikonu 5. Nešto je manja razlika izračunata i kod onih koji posjeduju radno iskustvo te onih koji ne posjeduju $(\mathrm{p}=0,035)$.

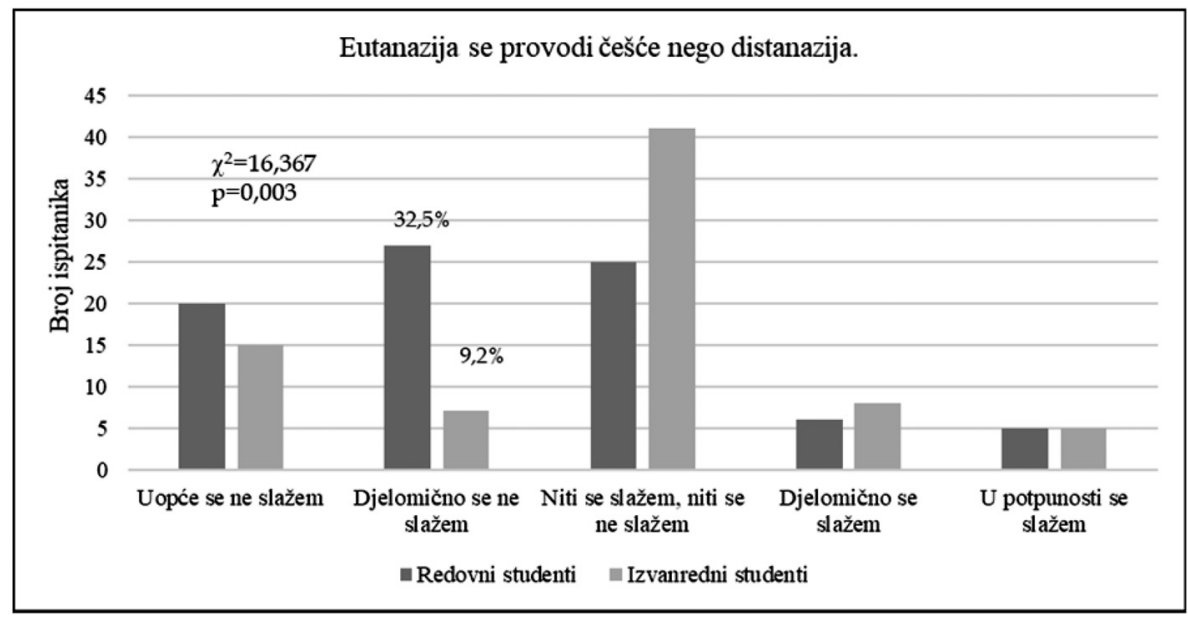

Grafikon 5. Učestalost provođenja eutanazije i distanazije.

Chart 5: Frequencies of performing euthanasia and dysthanasia.

Statistički značajna razlika između stavova redovnih i izvanrednih studenata $(\mathrm{p}=0,002)$, kao i nešto manja razlika između onih studenata koji imaju radno iskustvo i onih koji nemaju ( $\mathrm{p}=0,042$ ), dokazana je i kod prepoznavanja distanazije kao etičkoga problema u usporedbi s eutanazijom. Iako je na tvrdnju "Distanazija ne predstavlja etički problem za razliku od eutanazije" prema izračunu frekvencije najčešći odgovor bio neutralan, 21,2\% redovnih studenata izrazilo je djelomično neslaganje, a manji je dio izvanrednih studenata, tj. 5,2\% dao isti odgovor. Ista je situacija i s postojanjem radnoga iskustva. Naime, oni studenti koji nemaju radnoga iskustva u većoj su mjeri odbacili tvrdnju koja potvrđuje da distanazija ne predstavlja etički problem (usp. Grafikon 6). 


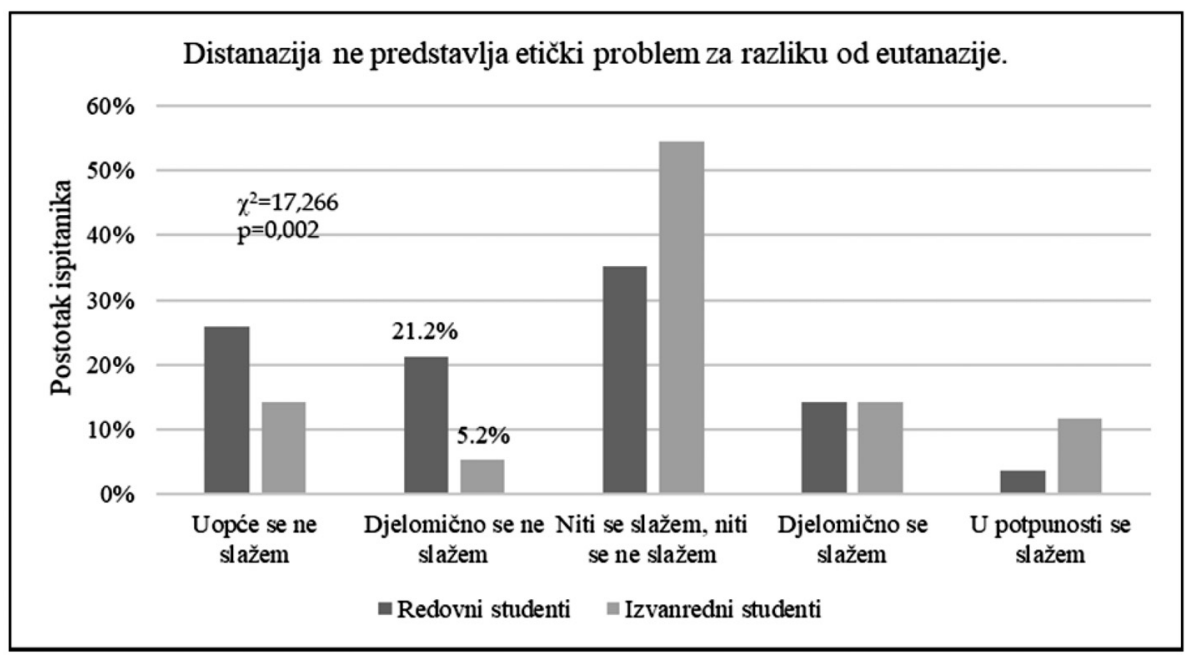

Grafikon 6. Etička prosudba distanazije i eutanazije

Chart 6: Ethical appraisal of dysthanasia and euthanasia

Pozitivna nepotpuna korelacija potvrđuje umjerenu povezanost tvrdnje "Liječnik ima pravo poduzeti sve što je u moći medicine kako bi produžio pacijentov život” sa sljedećim dvama izjavama: "Dok god postoji nada za život, ne može se ni jedan medicinski tretman smatrati beskorisnim i financijskim opterećenjem za društvo" $\left(\mathrm{r}_{\mathrm{s}}=0,521 ; \mathrm{p}<0,05\right)$ i "Opravdano je koristiti sva moguća i dostupna sredstva kako bi se produžio život bolesnika” $\left(r_{s}=0,581 ; p<0,05\right)$. To potvrđuje usporedni rast razine slaganja na prvu tvrdnju i na druge dvije tvrdnje. Također, malo se manja povezanost $\left(\mathrm{r}_{\mathrm{s}}=0,436 ; \mathrm{p}<0,05\right)$ pokazala kod poštivanja naloga za nevršenje reanimacije i pacijentova prava na odlučivanje o prekidu postupka. Kako raste razina slaganja s time da je moralno poštivati nalog za nevršenje reanimacije, tako raste razina slaganja s činjenicom da pacijent ima pravo odlučivati o svojem medicinskom tretmanu.

Distanazija kao takva postavlja pitanje do kada produžavati život, a transhumanizam na smrt gleda kao prijetnju i poniženje za čovjeka te tu granicu pokušava eliminirati. Pozitivna korelacija $\left(\mathrm{r}_{\mathrm{s}}=0,355\right.$; $\left.\mathrm{p}<0,05\right)$ uočena je između pitanja koja povezuju s jedne strane korištenje svih mogućih sredstava s ciljem produživanja života, a s druge strane pobjeđivanje čovjekove ranjivosti. Transhumanizam na ideju produženja čovjekova života gleda kao na priliku za ostvarenje i poboljšanje čovjeka, a medicina se kroz distanaziju uz sva moguća sredstva pokušava boriti protiv smrti i barem odgoditi ju na neko vrijeme. Postoji pozitivna povezanost $\left(\mathrm{r}_{\mathrm{s}}=0,581 ; \mathrm{p}<0,05\right)$ između tvrdnje koja opisuje liječnikove ovlasti da čini sve što je u moći medicine kako bi produljio pacijentov život i tvrdnje koja potvrđuje opravdanost korištenja svih mogućih sredstava kako bi se produžio život bolesnika. Također, slaganje s beziznimnom dobrobiti svih sredstava i načina koji produžuju život (s čime se dakako slažu transhumanisti) povezano je 
sa slaganjem ispitanika s činjenicom da se ni jedan postupak ne smije smatrati beskorisnim ako nada za život postoji $\left(\mathrm{r}_{\mathrm{s}}=0,361 ; \mathrm{p}<0,05\right)$.

Tablica 2. Vrijednosti $\chi^{2}$ testa - povezanosti vrste studija i radnoga iskustva s izjavama ispitanika ${ }^{2}$

Table 2. The value of $\chi 2$ test - the correlation between forms of study, work experience and participant statements

\begin{tabular}{|l|c|c|c|c|c|}
\hline \multicolumn{1}{|c|}{ Tvrdnja } & Mod & $\chi^{2}$ & $\mathrm{p}$ & $\chi^{2}$ & $\mathrm{p}$ \\
\hline $\begin{array}{l}\text { Produženje čovjekova života } \\
\text { značilo bi ispunjenje čovjeka u } \\
\text { njegovoj ljudskosti i ostvarenje } \\
\text { temeljnih čežnji. }\end{array}$ & 3 & 11,207 & 0,024 & & \\
\hline $\begin{array}{l}\text { Napredak medicine i tehnologije } \\
\text { u budućnosti će uspjeti potisnuti, } \\
\text { ako ne i ukloniti ranjivost } \\
\text { čovjeka.** }\end{array}$ & 3 & 11,922 & 0,018 & & \\
\hline $\begin{array}{l}\text { Ideje o napretku čovjeka ostat } \\
\text { ce uvijek samo dio znanstvene } \\
\text { fantastike. }{ }^{* * *}\end{array}$ & 3 & $* * 9918$ & $* * 0,042$ & $* 10,852$ & $* 0.028$ \\
\hline $\begin{array}{l}\text { Eutanazija se provodi češće nego } \\
\text { distanazija.*** }\end{array}$ & 3 & $* * 16,367$ & $* * 0,003$ & $* 10,325$ & $* 0,035$ \\
\hline $\begin{array}{l}\text { Moralno je poštivati nalog za } \\
\text { nevršenje reanimacije. }\end{array}$ & 5 & 9,794 & 0,044 & & \\
\hline $\begin{array}{l}\text { Distanazija ne predstavlja } \\
\text { etički problem za razliku od } \\
\text { eutanazije. }{ }^{* * *}\end{array}$ & 3 & $* * 17266$ & $* * 0,002$ & $* 9,721$ & $* 0,045$ \\
\hline $\begin{array}{l}\text { Pacijent ima pravo odlučiti o } \\
\text { tome želi li nastaviti primati } \\
\text { određeni medicinski tretman. }\end{array}$ & 5 & 16,550 & 0,035 & & \\
\hline
\end{tabular}

\section{Rasprava}

Glavni je izvor djelovanja transhumanizma umreženje raznih znanstveno-tehničkih grana u tzv. konvergentne tehnologije — nanotehnologija, biotehnologija, informatika i kognitivne znanosti (NBIC) - s ciljem poboljšanja čovjeka (Vuletić et al., 2016, 249; Mattei, 2016, 54-55). Prikazani rezultati pokazuju da postoji mala razlika u stavovima i prihvaćanju transhumanističkih ideja kako između redovnih i izvanrednih studenata, tako i između onih koji imaju radno iskustvo i onih bez radnoga iskustva. Spomenuta razlika može se protumačiti dobnom razlikom koja dijeli izvanredne i redovne studente te različitom upoznatošću i

2 Legenda: * statistički značajna razlika pronađena kod radnoga iskustva; ** statistički značajna razlika pronađena kod vrste studija; *** statistički značajna razlika pronađena kod radnoga iskustva i vrste studija. 
zainteresiranošću za nove tehnologije. Polazeći od poboljšanja čovjeka kao glavne odrednice transhumanističkih ideja (Cole-Turner, 2011), studenti prihvaćaju činjenicu da se čovjek može unaprjeđivati na svim razinama. Uzevši u obzir fizičko poboljšanje za koje transhumanizam daje mnoga rješenja, od bioničkih ruku, nogu, očiju, pa sve do bioničkoga mozga, ispitanici smatraju da bioničko uho ne predstavlja prijetnju samoj naravi čovjeka. Razlog tomu leži, moglo bi se reći, u poznavanju, ili bar intuitivnom razlučivanju između restorativnih i potencirajućih tehnologija, tj. onih tehnologija koje nadomještaju izgubljene funkcionalnosti, a ne proizvode nove koje nadilaze ljudsko te, kako ističu neki autori, nastaje homo cyborg (Greguric, 2018, 100; Garner, 2011, 87-92). Što se tiče produživanja života, studenti bez radnoga iskustva u većoj mjeri slažu se s činjenicom da produljenje života znači ispunjenje čovjeka u njegovoj ljudskosti, a oni s radnim iskustvom to u manjoj mjeri prihvaćaju i zapravo u većoj mjeri odbacuju takav stav. Na odgovore i stavove vezane uz perspektivu smrti i umiranja kod studenata bez radnoga iskustva zasigurno je utjecala činjenica da se nisu pod vidom sestrinske prakse previše susretali s procesom starenja i smrti. Radno iskustvo, ali i iskustvo života, kao i doticaj s umirućim pacijentima zasigurno doprinose razumijevanju čovjekove smrtnosti, prihvaćanju starenja kao nezamjenjivoga dijela čovjekova života, koje zapravo u raznim oblicima i naglascima oblikuje život pojedinca, ali i ljudi oko njega (Hercigonja-Kocijan, 1998). Za pretpostaviti je da su studenti bez radnoga iskustva u većini mladi ljudi u punoj snazi koji previše ne razmišljaju o starenju, starosti, životnom vijeku i daljoj budućnosti koja ih čeka, kao ni o godinama koje bi željeli doživjeti. Zanimljivo je primijetiti kako transhumanist Ray Kurzweil navodi da ljudi dok su mladi govore kako ne žele doživjeti veliku starost, ali kako stare sve više počinju razmišljati o smrti želeći živjeti što dulje. Također Kurzweil navodi kako je želja za životom usađena u čovjekovu narav, dio je njegove ljudskosti te da jedino oni koji na neki način pate i trpe zapravo žele završetak života (Nguyen i Will, 2015).

Vulnerabilnost čovjeka studenti prihvaćaju kao dio njegove ljudskosti i ne smatraju ju problemom i poniženjem čovjeka, ali s druge strane smatraju kako ju ne treba samo prihvaćati, nego treba činiti sve kako bi ranjivost bila pobijeđena. To se može shvatiti kao djelomično nerazumijevanje pojma vulnerabilnosti, tj. ranjivosti čovjeka, što ona predstavlja i koje je njezino značenje za čovjeka i njegovu narav, što zapravo ljudska ranjivost predstavlja te znači li podložnost bolestima i smrti čovjeku nekakvo ograničenje i poniženje, ili mu daje priliku za poniznost i priznanje nemoći (Vučković, 2017; Nikić, 2017). Odgovor na ta pitanja daje upravo sestrinska profesija. S time su se složili i studenti, izjasnivši potpuno slaganje s činjenicom da je ranjivost ključno pitanje u sestrinskoj profesiji jer joj je cilj pomoći pacijentu i zaštititi ga. Uzevši u obzir ostale stavove studenata o ljudskoj vulnerabilnosti, uviđa se da je stav o ranjivosti kod ispitanika primarno negativan, no ona zapravo može biti i jest izvor nečega pozitivnoga. O tome piše Martina Vuk $(2019,33)$ navodeći da ranjivost čovjeka »apelira na ograničenost čovjekove egzistencije i njegovu potrebu za drugim«. Jednako tako, valja biti svjestan da je »iskustvo golotinje, od rođenja sve do smrti, u srcu nje- 
gova [čovjekova] dragocjenoga identiteta. Prihvatiti vlastitu ranjivost za svakoga je ponajprije pitanje lucidnosti. To znači prihvatiti svoju povijest bez nijekanja svojega podrijetla« (Derville, 2016, 259, preveo: Odilon-Gbènoukpo Singbo). Upravo su se u kontekstu toga smjestili cilj i poslanje sestrinske profesije. No napredak medicine $\mathrm{i}$ »proces tehnologizacije kliničke prakse « (Matulić, 2005, 40) u korijenima mijenjaju osnovne značajke sestrinske skrbi. Oko toga hoće li napredak pružiti čovjeku odbacivanje ranjivosti studenti su podijeljenoga mišljenja. Gotovo jednak broj studenata prihvaća tu izjavu, kao što ju i odbacuje, no svakako valja primijetiti da izvanredni studenti u većoj mjeri prihvaćaju takav stav, za razliku od redovitih.

Dokazane razlike u stavovima među studentima nisu velike, no uzrok razlike može biti dob, ako se pretpostavi da su redovni studenti mlađe dobi od izvanrednih. Mlađe su osobe više upućene u razvoj tehnologije, žive u neposrednoj povezanosti s njom, što je posljedično možda dovelo do neosjetljivosti na njezinu problematiku i neprepoznavanje već prisutnih promjena i svekoliko beziznimno prihvaćanje bilo kakvoga napretka. Izvanredni studenti, koji u većini imaju radnoga iskustva u struci, starije su dobi od redovnih studenata te s opreznošću gledaju na tehnološki napredak. Zaključno, i redovni i izvanredni studenti, odnosno oni s radnim iskustvom i oni bez njega, na velik su broj pitanja vezanih za transhumanizam odgovorili neutralnim odgovorom, što pokazuje njihovu nedovoljnu upućenost u tematiku i problematiku koja stoji iza transhumanističkih ideja, a koje se neminovno tiču sestrinske profesije.

Najčešći je odgovor na pitanje o definiciji distanazije neutralan (38,3\%). Iz toga se zaključuje kako studenti nisu previše upućeni u tematiku distanazije, kao ni u njezinu definiciju.

U Brazilu je 2015. godine provedeno istraživanje među studentima sestrinstva $\mathrm{s}$ ciljem ispitivanja poznavanja pojma distanazije i njezine pojave u praksi. Rezultati su pokazali da $85 \%$ ispitanika ne zna ili se ne sjeća definicije distanazije (Matos et al., 2015, 815-825). Studenti preddiplomskoga studija sestrinstva $\mathrm{Hr}$ vatskoga katoličkoga sveučilišta u malo većoj mjeri poznaju taj termin od brazilskih studenata, no i dalje nedovoljno s obzirom na izrazito čestu provedbu procesa distanazije. Redoviti studenti u malo su većoj mjeri nego izvanredni studenti izrazili potpuno neslaganje s mišljenjem da distanazija označava dostojanstvenu smrt.

Kad se govori o dostojanstvenoj smrti, u medijima se često čuje asocijacija na eutanaziju. Ona je rjeđe zastupljena od distanazije, a o njoj se češće govori. U Meksiku je 2015. među zdravstvenim djelatnicima koji rade na odjelima intenzivne skrbi provedeno istraživanje (Olivares-Durán i Madrigal-Arcos, 2015, A655). Rezultati su pokazali da je $72 \%$ ispitanika (liječnici, medicinske sestre) sudjelovalo u vršenju distanazije. Distanazija još uvijek nije postala predmet rasprave jer »još uvijek postoji šutnja, suučesnica etičke nepripremljenosti koja stvara malodušnost u transparentnom i poštenom razmatranju ovoga pitanja « (Pessini, 2004, 300). Govor o distanaziji započinje trenutkom kada je, kako navodi Pessini (2004, 26), »stručno znanstveni napredak započeo u odlučujućem obliku utjecati na finalnu fazu ljudskog života«. Bez obzira na medicinsku tehno- 
logiju koja se enormnom brzinom razvija, pojam distanazije ostaje nepoznat ne samo široj javnosti, nego i medicinskim djelatnicima. No, zanimljivo je primijetiti povećanje broja publiciranih članaka na tu temu u vremenskom razdoblju od 15 godina. Naime, u članku Dysthanasia: the (il)legitimacy of artificially posponed death autori navode kako su pretraživanjem baze Medline za izraz disthanasia pronašli 2 rezultata, a za izraz dysthanasia 10 (Sorta-Bilajac Turina et al., 2005, 3). Za ovaj članak iste smo pojmove pretražili 2020. godine i dobili smo sljedeće rezultate: disthanasia (4 članka), dysthanasia (35 članaka - najnoviji iz 2020. godine). Primjećujemo povećan broj publiciranih članaka na tu temu, no i dalje taj broj je relativno malen s obzirom na njezinu zastupljenost u praksi. Stoga se usuđujemo reći kako je i dalje prisutna nedovoljna zainteresiranost za tako bitnu i aktualnu temu.

S obzirom na rezultate ankete, neutralni odgovori pokazuju određenu razinu neupućenosti studenata, posebice kada je riječ o usporedbi eutanazije i distanazije. Razlog tomu nalazi se u prethodno spomenutom medijskom izdvajanju eutanazije nad distanazijom, koje "polazi od jednog redukcionističkog i kratkovidnog gledanja koje sve pojednostavljuje na dva gledišta: biti za ili protiv« (Pessini, 2004, 23). Pojednostavljivanje i relativiziranje etičkih problema vezanih za pojedine medicinske postupke dovelo je do neosjetljivosti ljudi na te moralno upitne postupke. Kako rezultati pokazuju, redovni studenti u većoj su mjeri nego izvanredni prepoznali distanaziju kao etički problem. Kako nisu u procesu rada, nego u procesu učenja od početka te nisu zaokupljeni određenim područjem rada kao izvanredni studenti, koji su više usmjereni na svoja područja rada, redovni studenti mogu biti više zainteresirani za područje bioetičkih pitanja vezanih uz struku. No bez obzira na to, i dalje se može govoriti o nedovoljnoj informiranosti o tematici.

Gledajući ishode distanazije kao procesa, posljedice trpi i pacijent i njegova obitelj. Studenti smatraju kako produživanje života bolesnika ne smanjuje patnju pacijentu i obitelji. Nadalje, što se tiče uporabe sredstava za produživanje života, studenti smatraju kako se nijedan medicinski postupak ne može smatrati beskorisnim ako postoji nada za život te kako liječnik ima pravo činiti sve što je u moći medicine kako bi produžio život. S jedne strane studenti izražavaju razumijevanje o posljedicama produljenja života u vidu povećanja i produljenja patnje, a s druge strane zagovaraju korištenje svih mogućih sredstava s ciljem produljenja života. To je potvrdila i povezanost koja postoji između tih dvaju pitanja. Jedan stav pobija drugi, tj. ako se promatra suprotnost danih odgovora, to ponovno pokazuje nepoznavanje i nerazumijevanje cjelokupnoga procesa distanazije.

Nepoznavanje termina distanazije, eutanazije, ali i drugih koncepata etički upitnih postupaka, odmaže zdravstvenim djelatnicima u pružanju adekvatne skrbi s ciljem očuvanja dostojanstva ljudskoga bića. To je posebice bitno u sve većem broju bolnica koje posjeduju visoku tehnologiju, pa autonomija i reputacija liječnika pada u drugi plan jer glavnu ulogu zauzima tehnologija (Tomašević, 2004).

U Brazilu je 2009. godine provedeno istraživanje među studentima sestrinstva kojim se kroz anketu upitalo studente bi li im znanje s područja 3 koncepata 
(distanazije, ortotanazije i eutanazije) pomoglo u radu i doprinijelo stručnosti te bi li ga mogli primjenjivati u svakodnevnoj praksi. 70\% studenata izjasnilo se je potvrdno i objasnili su da bi im pomoglo u pružanju odgovarajuće skrbi u danom trenutku (Biondo et al., 2009).

Studija koja je provedena u Iranu 2015. godine potvrdila je da je svijest o iskustvima sestara u vezi s distanazijom prvi korak prema uspostavljanju učinkovitih terapijskih, obrazovnih i istraživačkih programa u sestrinskoj praksi, jer medicinske sestre igraju ključnu ulogu u upravljanju neučinkovitim postupcima (Yakefallah et al., 2015). Na tragu toga u Hrvatskoj već neko vrijeme postoji tendencija o obrazovanju medicinskih sestara o etičkim dilemama (Sorta-Bilajac et. al., 2007) osobito o najzastupljenijoj etičkoj dilemi u svakodnevnoj sestrinskoj praksi - povlačenju sredstava održavanja na životu (Sorta-Bilajac Turina et al., 2011, 347). Stoga, bitno je poraditi na obrazovanju medicinskih sestara na području bioetike, filozofskoga i teološkoga poimanja dostojanstva ljudske osobe, umiranja i smrti, jer im razumijevanje svakoga segmenta etički problematičnih postupaka pomaže u pružanju skrbi.

Jedan od procesa i postupaka koji se u okviru transhumanističkih ideja uz pomoć raznih medicinskih i tehnoloških dostignuća, a u vidu produžetka života često provodi u bolnicama upravo je distanazija. Transhumanizam i distanazija povezani su u smislu da distanazija naglasak stavlja na produženje života (ne na kvalitetu života), a transhumanizam naglašava produženje života uz kvalitetu poboljšanje. Iako se ispitanici slažu s tvrdnjom da kvaliteta života ima veću važnost od produženja života (u vidu distanazije), prihvaćaju održavanje na životu pacijenata u trajnom vegetativnom stanju te ujedno veći dio smatra kako je bolji život u znanstveno-tehnološkom smislu uvijek ispunjen smislom (u vidu transhumanizma). Tu se ponovno može govoriti o neupućenosti ispitanika primarno u vezi s distanazijom, a potom is transhumanizmom.

Transhumanizam svoje ideje želi ostvariti i ostvaruje uz sva moguća dostupna sredstva, a vodi ga misao da cilj opravdava sredstvo te da je bitno da pojedinac u svojoj slobodi izabere sredstva za ostvarenje spomenutoga poboljšanja (Sandberg, 2013). Te su ideje jasno i nedvojbeno istaknute u osam točaka deklaracije transhumanizma (Bostrom, 2005). Kako raste slaganje studenata s činjenicom da treba produžiti čovjekov život svim mogućim sredstvima, raste i slaganje s tvrdnjom da čovjek svoju ranjivost ne bi trebao samo prihvaćati, nego činiti sve kako bi ju pobijedio. Nadalje, što se ispitanici više slažu s iskorištavanjem moći medicine radi produživanja života, to se više slažu i s tvrdnjom da se sve što može pobijediti bolest i produžiti život može smatrati beziznimnim dobrom. Povezanosti među pitanjima pokazuju da uglavnom kako rastu slaganja za tvrdnje vezane za distanaziju, raste i razina slaganja na tvrdnje koje opisuju transhumanističke ideje.

Kod studenata se uviđa neprepoznavanje te istovremeno nepoznavanje pokreta transhumanizma koji »nije po sebi novi, ali pomalo poprima konkretne i opipljive sadržaje i njihovo ostvarenje (Singbo, 2019, 18). Jedan je od tih sadržaja svakako produživanje života, koje se trenutno provodi u obliku distanazije uz pomoć raznih medicinskih i tehnoloških dostignuća. Primarno je za medicinske 
sestre upoznati izazove koje nosi razvitak tehnologije i njihov utjecaj na čovjekov život, kako pozitivno, tako i negativno.

\section{Zaključak}

Uz mnoge dobrobiti koje donosi razvitak znanosti i tehnologije, javljaju se novi problemi i izazovi, od kojih se neki tiču terapijske upornosti, intervencija na čovjeku i u čovjeku, a velik broj njih ukomponirani su u filozofski, kulturni i znanstveni pokret transhumanizma. Glavno etičko pitanje koje se javlja upravo je pitanje ljudskoga dostojanstva. Iz perspektive problematike distanazije govori se o dostojanstvenom umiranju, koje nikako ne može podrazumijevati produljivanje patnje i umiranja. U kontekstu transhumanizma, dostojanstvo se dijeli na dva dijela: dostojanstvo humanih i dostojanstvo posthumanih, koje posljedično može naštetiti običnim ljudskim bićima. Također, uz sve intervencije kojima je cilj poboljšanje čovjeka u bilo kojem smislu, tu se možda najvažnije u smislu produženja života postavlja pitanje što je čovjek i ostaje li on čovjekom.

Istraživanje provedeno među studentima Hrvatskoga katoličkoga sveučilišta dalo je prethodno iznesene rezultate te se iz prikupljenih podataka i rezultata zaključuje sljedeće: 1 . Postoji razlika u stavovima o prihvaćanju transhumanističkih ideja između izvanrednih i redovnih studenata. 2. Postoji razlika u poznavanju tematike te razlikovanju distanazije i posljedica napretka između redovnih i izvanrednih studenata. Također, razlika se uviđa između onih koji posjeduju radno iskustvo u struci i onih koji ne posjeduju. 3. Redovni studenti pokazuju bolje poznavanje tematike distanazije, ali isto tako i veće prihvaćanje transhumanističkih ideja od izvanrednih studenata. 4. Izvanredni studenti pokazuju veću osjetljivost i oprez prema izazovima koje donose nove medicinske tehnologije od redovnih studenata. 5. Kod studenata je prisutna nedovoljna upućenost u problematiku i etičke izazove koje donose nove medicinske tehnologije. Na osnovu rezultata ovoga istraživanja možemo zaključiti da postoji potreba za daljnjim educiranjem i upoznavanjem biomedicinskih djelatnika o tim dvjema tematikama, kako onih koji su već duboko uronjeni u praksu kroz različite tečajeve usavršavanja, tako i onih koji se spremaju zakoračiti u nju u okviru postojećih obrazovnih programa.

\section{Literatura}

Biondo, Chaiane Amorim; Paes, Maria Júlia Paes da; Secco, Lígia Maria Dal (2009). Dysthanasia, euthanasia, orthotanasia: the perceptions of nurses working in intensive care units and care implications. Revista Latino-Americana de Enfermagem, 17(5), 613-619.

Bostrom, Nick (2005). A history of transhumanist thought. Journal of Evolution and Technology, 14(1), 1-25.

Cole-Turner, Ronald (2011). The transhumanist challenge. U: Ronald Cole-Turner (ur.), Transhumanism and Transcendence Christian Hope in an Age of Technological Enhancement (str. 2-17). Washington, DC: Georgetown University Press.

Derville, Tugdual (2016). Le temps de l'homme: Pour une révolution de l'écologie humaine. Paris: PLON. 
Garner, Stephen (2011). The hopeful cyborg. U: Ronald Cole-Turner (ur.), Transhumanism and Transcendence Christian Hope in an Age of Technological Enhancement (str. 87-100). Washington, DC: Georgetown University Press.

Greguric, Ivana (2018). Kibernetička bića u doba znanstvenog humanizma: Prolegomena za kiborgoetiku. Zagreb: Hrvatsko filozofsko društvo.

Hercigonja-Kocijan, Dubravka (1998). Psihološki aspekti umiranja i smrti. Crkva u svije$t u, 33(1), 21-29$.

Matos, Mariana; Rosa, Darci; Anjos, Karla (2015). Knowledge of nursing students on dysthanasia. Revista da Rede de Enfermagem do Nordeste, 16(6), 817-825.

Mattei, Jean-Francois (2016). La médecine, référence ou alibi du posthumanisme? U: Yves Caseau (ur.), L'homme augmenté conduit-il au transhumanisme? (str. 51-63). Paris: Parole et Silence.

Matulić, Tonči (2005). Bioetičko tematiziranje ljudskog umiranja: Umiranje u procjepu medicinskog tehnicizma i ontoantropološkog "personizma". Crkva u svijetu, 40(1), $29-62$.

Nguyen, Christine; Wei, Will (2015). The world's leading futurist wants to live forever - here's why. Business Insider Australia, 3. studenoga. URL: https://www.businessinsider.com.au/futurist-ray-kurzweil-eternal-life-technology-2015-11 (06.07.2020.) [Video.]

Nikić, Mijo (2017). Smrt nije definitivni kraj. Psihološko-duhovni pristup. U: Ivan Markešić (ur.), Čovjek i smrt: Teološki, filozofski, bioetički i društveni pristup (str. 87-90). Zagreb: Hrvatsko katoličko sveučilište.

Olivares-Durán, E. M.; Madrigal-Arcos, A. M. (2015). Dysthanasia and/or futile care in the intensive care units of a specialty hospital in el Bajío region, in Mexico. Intensive Care Medicine Experimental, 3(1), A655.

Pessini, Leo (2004). Distanazija: Do kada produžavati život. Rijeka: Adamić.

Sandberg, Anders (2013). Morphological freedom: Why we not just want it, but need it. U: Max More i Natacha Vita-More (ur.), The Transhumanist Reader: Classical and Contemporary Essays on the Science, Technology, and Philosophy of the Human Future (str. 56-64). Oxford: Wiley-Blackwell.

Singbo, Odilon (2019). Transhumanizam i obećanje budućeg (boljeg) života. Kana, 50(541), 18-20.

Sorta-Bilajac Turina, Iva; Pessini, Leo; Dobrila-Dintinjana, Renata; Hozo, Izet (2005.) Dysthanasia: the (il)legitimacy of artificially posponed death. Medicinski arhiv, 59(3), 199-202.

Sorta-Bilajac, Iva; Brkanac, Domagoj; Brozović, Boris; Bazdarić, Ksenija; Brkljacić, Morana; Pelcić, Gordana; Golubović, Vesna; Segota Ivan (2007.) Influence of the "Rijeka model" of bioethics education on attitudes of medical students towards death and dying - a cross sectional study. Collegium antropologicum, 31(4), 1151-1157.

Sorta-Bilajac Turina, Iva; Brkljacic, Morana; Baždarić Ksenija; Jančić, Ervin (2011.) How Nurses and physicians face ethical dilemmas - the Croatian experience. Nursing ethics, 18(3), 341-355.

Tomašević, Luka (2004). Do kada produžavati život? Služba Božja, 44(2), 143-146.

Vučković, Ante (2017). Čovjek i smrt. U: Ivan Markešić (ur.), Čovjek i smrt: Teološki, filozofski, bioetički i društveni pristup (str. 69-74). Zagreb: Hrvatsko katoličko sveučilište.

Vuk, Martina (2019). Ljudska ranjivost: prijetnja ili prilika? Kana, 50(540), 32-33.

Vuletić, Suzana; Filajdić, Željko; Ivančičević, Marko (2016). Transhumanistička eugenika: Protetička kiborgizacija ljudskog poboljšanja nanomedicinskim zahvatima. U: 
Marijan Steiner i Ivan Šestak (ur.), Aktualne moralne teme (str. 245-268). Zagreb: Filozofsko-teološki institut Družbe Isusove.

Vuletić, Suzana; Juranić, Brankica; Mikšić, Štefica; Rakošec, Željko (2014). Biomedicinski i moralno-etički aspekti distanazije: U agoniji umiranja pred medicinskom beskorisnošću. Diacovensia, 22(2), 163-200.

Yekefallah, Leili; Ashktorab, Tahereh; Manoochehri, Houman; Hamid, Alavi Majd (2015). Nurses' experiences of futile care at intensive care units: a phenomenological study. Global Journal of Health Science, 7(4), 235-242.

The understanding of dysthanasia and transhumanism from the nursing profession perspective

$$
\text { Terezija Gložinić*, Odilon-Gbènoukpo Singbo**, Anto Čartolovni**** }
$$

\section{Summary}

This paper presents the research results from a quantitative research study about the attitudes of undergraduate nursing students at the Catholic University of Croatia. The primary aim of this study was to investigate attitudes regarding the practice of life prolongation, therapeutic persistence, i.e. dysthanasia, and how transhumanist ideas impact students' lives and their (future) nursing profession. Furthermore, the research study aimed to inquire about general attitudes on death and life prolongation. One hundred sixty-four undergraduate students participated in this study, including both full-time and part-time students. The respondents were surveyed by means of a questionnaire specially designed to inquire into both of these topics. After analysis, the results showed significant differences in attitudes and in the understanding of the terms dysthanasia and transhumanism among the respondents with and without work experience, and among full-time and part-time students. Nevertheless, results demonstrated that having work experience does not impact one's understanding of dysthanasia, and a greater knowledge of the transhumanist ideal does not decrease acceptance of transhumanist ideas. Probably the most interesting of our results points to the fact that work experience significantly contributes to the creation of a precautionary attitude towards new medical technologies.

Keywords: dysthanasia; transhumanism; euthanasia; vulnerability; nursing profession; life prolongation; technology

* Terezija Gložinić, B.S.N., Department of Nursing, Catholic University of Croatia. Address: Ilica 242, 10000 Zagreb, Croatia. E-mail: tglozinic@unicath.hr

** Odilon-Gbènoukpo Singbo, Ph.D., Chair of Theology, Catholic University of Croatia. Address: Ilica 242, 10000 Zagreb, Croatia. E-mail: odilonsing@gmail.com

*** Anto Čartolovni, Ph.D., Digital Healthcare Ethics Laboratory (Digit-HeaL), Catholic University of Croatia. Address: Ilica 242, 10000 Zagreb, Croatia E-mail: anto.cartolovni@unicath.hr 